\title{
Introduction. Mining Imagination: Ethnographic Approaches Beyond the Written Word
}

\author{
Michaela Schäuble
}

\section{OpenEdition}

\section{Journals}

\section{Electronic version}

URL: http://journals.openedition.org/anthrovision/2407

DOI: 10.4000/anthrovision.2407

ISSN: 2198-6754

\section{Publisher}

VANEASA - Visual Anthropology Network of European Association of Social Anthropologists

\section{Electronic reference}

Michaela Schäuble, «Introduction. Mining Imagination: Ethnographic Approaches Beyond the Written Word », Anthrovision [Online], 4.2 | 2016, Online since 31 December 2016, connection on 19 April 2019. URL : http://journals.openedition.org/anthrovision/2407 ; DOI : 10.4000/anthrovision.2407

This text was automatically generated on 19 April 2019

(c) Anthrovision 


\title{
Introduction. Mining Imagination: Ethnographic Approaches Beyond the Written Word
}

\author{
Michaela Schäuble
}

1 Are there ethnographic approaches that are particularly suited to elicit and communicate unarticulated experiences and concealed understandings of the world? What methods and media techniques would be most appropriate to unearth or mine such realms? Which aesthetic practices are aimed at the description or mimetic replication, and which ones at the construction or creation of (a new) reality or experience?

2 This special issue is the result of conversations initiated around these questions on occasion of a workshop held at the Mahindra Humanities Center at Harvard University ( Mining Imagination: Ethnographic Approaches Beyond Knowledge Production) in April 2013. ${ }^{1}$ As the workshop convener, I had called for critical and creative explorations of anthropological ways of knowing and experiencing the world that might bring the written word to the test. ${ }^{2}$ I was particularly interested in the more-than-representational power of ethnographic inquiry and contributors were invited to "mine imagination" beyond and outside an essentially realist and mimetic paradigm.

3 Referring to imagination in an anthropological context is to either land immediately in a discussion on the ambivalent role of the concept in Western philosophy, notably in relation to phenomenological thought and method, or in suggesting alternative, experimental avenues of non-textual communication of anthropological knowledge and the sensorial dimensions of being. And although both reactions constituted a vital part of our approaches and discussions, we did not leave it at that. All participants were careful to avoid the naive illusion of immediacy and unmediated access to hitherto hidden spheres, and to move beyond enthusiastically proclaiming the power of the sensorial and non-written world by critically assessing and reflecting on the epistemological conditions and ekphrastic limitations of the new methodologies and technologies - such as augmented reality, virtual intimacy, sound walks, the audio-visual exploration of thoughtscapes, corporeal states of trance, etc. - presented. 
While acutely aware of the habitual denigration of imagination in the Western tradition in philosophy and its exclusion from the pursuit of objective knowledge and/or insight (but also its reverse idealization by the German and English Romantics and French surrealists), we could not but notice the almost paradoxical essentiality of imagination's use in philosophical methodology, especially as phenomenological technique (Sallis 2000; Casey 1977). However, the act of imagining that refers to immaterial knowledge as much as to experiential reality, and that is involved in coming to understand something about and making sense of the world, not only features prominently in art, cognitive psychology and philosophy, but is as well an important constituent of anthropological methodology; the research practices of most ethnographers does indeed presume and aim at imagining other people's experiences.

5 Apart from the awareness that imagination is a methodological a priori in anthropology, in the workshop we also established that the practice of imagining itself is essential to human mental activity and human experience, and is embedded in our material existence. ${ }^{3}$ Taking the proposition of Edward S. Casey serious that imagining is not the mere offshoot or pale replica of perception - because we cannot regard as derivative from perception what is constitutive of perception itself -, imagination emerges as central in any appraisal that attempts to do justice to human experience in its full variety and ramifying richness.

Nigel Rapport and Mark Harris (Rapport and Harris 2015) have recently framed the challenge that imagination poses to anthropology. With reference to James Preston's coupling of the imaginative and the poetic (Preston 1991), they assert that these two domains, the imaginative and the poetic, are key to understanding the human condition (Harris 2015: 6). Defining imagination as an "individually embodied capacity, ontologically transcendent of setting (other than the body), which impacts on the material world" (Rapport 2015: 7), Rapport highlights the aspect of imagination's individual agency and practice that happens alongside others who are themselves involved in imaginative operations. As such, imagination is "foundational of our physical dwelling within environments and our intellectual-cum-emotional appreciation of them" (Rapport 2015: 20). It is this combination of embodied and mental acts and the resonance of imagination on the material world that makes imagination such an important issue for the anthropological project.

7 The currently re-invigorated interest in imagination within anthropology (Bloch 2016: 81; Severi 2015 [2007], 2004; Ingold 2014; Sneath et. al. 2009; Crapanzano 2004; $)^{4}$ and its reconceptualization beyond the visual is, in my view, also owed to the rise of interpretative ethnography - or, in the words of David Graeber the prevalence of "interpretive labor" (Graeber 2012) within the discipline - and the exploration of new types of experimental texts (i.e. performance-based texts, literary journalism, ethnographic poetics, narratives of the self, etc.), as well as to further techno-scientific innovations and focal shifts towards embodied experience and perception (i.e. crossspecies communication, virtual social media, "artificial" intelligence, bioethics, etc.) reflected in the so-called "sensory turn" (Cox, Irving and Wright 2016). In an attempt to decouple imagination from the ability to create images, Vincent Crapanzano asked "But can we not "imagine" the beyond in musical terms? In tactile or even gustatory and olfactory ones? In propriocentric ones? In varying combinations of these - and perhaps even other - senses?" (Crapanzano 2004: 23). The apparent ineffability of imagination lends itself to be approached and grasped as phenomenon or technique that involves the 
entire human sensorium. This can be traced back to a tradition - mainly based on Aristotle's and Kant's equation of the (internal) image as mediating representation (Casey 1974: 5) - of ascribing imagination the role of an intermediary between sensation and thought, and has also informed a number of more cognitively oriented approaches. ${ }^{5}$

In recent years, however, the subdiscipline "anthropology of the senses', or "sensory ethnography"and concomitant applied approaches have gained momentum, revealing a strong interest in others' embodied experiences and interior lives. Sarah Pink, for example, utilizes sensory ethnography to come to a "closer to understanding how other people experience, remember and imagine" (Pink 2015: 25), while an institution such as the Sensory Ethnography Lab at Harvard University (SEL) ${ }^{6}$ "encourages attention to the many dimensions of the world, both animate and inanimate, that may only with difficulty, if it all, be rendered with propositional prose". Methodologically such approaches aim at combining image, sound, text and object to fathom and evoke sensory experience and/or active forms of sensory engagement where anthropological knowledge can emerge.

9 Along these lines, Tim Ingold in his recurring swansong to the use of the term "ethnographic" has recently called for reasserting the value of anthropology as a "forward-moving discipline dedicated to healing the rupture between imagination and real life" (Ingold 2014: 383). This assessment strongly resonates with Arjun Appadurai's earlier take on imagination as a social practice where he conceptualizes imagination as central to all forms of agency, and describes its capacities, amongst other things, as "form of negotiation between sites of agency (individuals) and globally defined fields of possibility" (Appadurai 1996: 31). Transferring this applied communal notion of imagination from the sphere of progressive social activism back to general anthropological theory and practice, Ingold concludes that "theory, when it turns, is no longer theory, but an imagination nourished by its observational engagements with the world. The rupture between reality and imagination-the one annexed to fact, the other to theory-has been the source of much havoc in the history of consciousness" (Ingold 2014: 395). Described as nourished by observational engagement with the world, imagination is therefore no longer conceptualized as an individual matter of the mind or psyche, but as an integral part of ethnographic practice that has also to be understood as an active force and shared commitment, immanent in a reality, that creatively shapes and transforms the socio-historical.

10 Already in the mid-19 $9^{\text {th }}$ century Charles Baudelaire had argued that the significance of imagination lies in the extent to which "[...] it creates a new world, it produces the sensation of newness" (Baudelaire 1981 [1859]: 156). And this sensation of newness is probably most virulent in relation to technological innovations, notably with regards the medium film as a new sensational technology that subjectively transforms human experience and imagination. ${ }^{7}$ The invention of technical images - images produced by technical media such as photographs, films, videos, etc. - revived the previous dream to make the invisible visible and provoked a reconsideration of the power of imagination. As early as in 1916 Hugo Münsterberg, a German experimental psychologist at Harvard, applied his science of perceptual techniques to the then new medium of cinema, or the photoplay as he called it, to show that the cinematic apparatus can induce mental processes. He was convinced that the photoplay had the capacity to produce new experiences of time and space. "The photoplay tells us the human story by overcoming the forms of the outer world, namely, space, time, and causality, and by adjusting the 
events to the forms of the inner world, namely attention, memory, imagination, and emotion" (Münsterberg 2005 [1916]: 170). Münsterberg also believed that "[i]n the photoplay our imagination is projected on the screen" (2005: 45). The same year Vachel Lindsay (1879-1931) praised cinema as a technology and artistic form for its ability to directly assault the viewer's senses and to manifest pure ideas (Lindsay 2004 [1916]; cf. Moore 2000: 48-61). The effectiveness of the photoplay unburdened by mimesis or representation became a major trope in the development of film theory. In a similar vein, Béla Balázs' works on early cinema, Der sichtbare Mensch (Visible Man, 1924) and Der Geist des Films (The Spirit of Film, 1930), refer to the huge potential of human imagination that is released by film as a new art form and technology.

11 One of the problems, of course, was that "from the beginning too much was expected of cinema", as Scott MacDonald so aptly put it (MacDonald 2013: 314). And in the long run, as we all know, neither documentary nor fiction film focused on the medium's "ability to signify non-referentially" (Flitterman-Lewis 1996: 120) or managed to radically break with traditional notions of representation, as early film critics had envisioned. But even if the expectations of film to produce entirely new meanings, or to generate a specific imaginative "photoknowledge" (Münsterberg 2005 [1916]: 17) might have failed, the desire to trouble commonsense perception of reality and to gain access to un-observable details of the human condition (while maintaining a space for the ineffable and inexplicable) remains - especially in contemporary social theory.

The special issue on hand will take this desire into account, though evidently none of the contributors claims to be able to access imagination, or other interior conditions, through empirical means. However, all assembled authors present various approaches to mining imagination, conceding that each approach and each piece can reveal something different from what gets revealed in a written text alone. While the individual inputs empirically explore the heterogeneous processes through which concrete imaginings come about, the issue as a whole is meant to further an ethnographic engagement with "technologies of the imagination" (Sneath et. al. 2009), understood as approaches by which imaginative workings and effects are mined and/or engendered.

With their contributions, Andrew Irving, Louis Kaplan and Melissa Shiff, and Ernst Karel take the readers on multisensory walking tours. Whether this is exploring the imaginative and inner lifeworlds of random strangers we pass every day on the street (Irving), walking through an augmented reality (Kaplan and Shiff), or a soundwalk through a Hindu temple in Tamil Nadu (Karel), all three pieces contemplate the material embeddedness and experiment with the moving dimension of imagination.

The Lives of Other Citizens by Andrew Irving is part of a long-term ongoing project in which he is developing and testing practical approaches to knowing, theorizing and representing the interior dimensions of being and its relationship to social life. Assuming that people's inner expressions and imaginative lifeworld constitute an essential feature of the human condition (through which people understand themselves and others), Irving's aim is to grasp his informant's imaginations, their thoughtscapes, in action. Methodologically, he is drawing on his practice-based research project New York Stories in which he is recording the private monologues of strangers in the streets of New York City as they speak their thoughts to themselves, wearing a small microphone. Irving is well aware, of course, that his research question "what are these people thinking?" lies beyond the limits of scientific methods and anthropological knowledge; but he nevertheless attempts to consider the relationship between thought, embodied 
movement/walking, and the urban environment - and indeed obtains some remarkable glimpses into the invisible realms of people's inner expression and experience. Entirely relying on random encounters and contingencies, Irving understands ethnography itself as an essentially imaginative act, thus supporting yet playfully challenging Nigel Rapport's assessment that "I imagine alongside my informants albeit that precisely how and what they imagine is hidden from me by our discrete embodiments" (Rapport 2015:8). In his contribution, Irving presents some of his findings in various audio-visual formats and invites readers, among other things, to download and listen to a stream of strangers' thoughts as they themselves walk down the streets.

In Mapping Ararat: An Augmented Reality Walking Tour for an Imaginary Jewish Homeland Louis Kaplan and Melissa Shiff invite their audiences to embark on a very different kind of imaginary journey. Using augmented reality (AR), their project animates an early $19^{\text {th }}$ century plan to transform Grand Island, New York into Ararat, a "city of refuge for the Jews." The original proposal of a Major Mordecai Noah was never realized, of course, and remained in the realm of the hypothetical and imaginary. Yet through a 3D modeling software, the authors have managed to transform Grand Island virtually into Ararat by placing augments into the landscape. The application uses geolocation software to superimpose virtual objects at precise GPS coordinates, enabling visitors to see the objects integrated into the physical location as if they existed in the real world. So with mobile devices in hand, visitors can now take an onsite walking tour and interact with augmented artifacts and monuments. The article in this special issue presents the public art project as a novel form of virtual Jewish tourism and conceptualizes it as kind of "counterfactual ethnography" engaging with both, an imaginary or virtual space (Ararat) and an actual locale (Grand Island). The contribution incorporates documentary photography and video clips exploring previous user's social interactions with place (the real world and the virtual) and with technology. The readers are invited to imagine what it would be like had Noah's plan to turn Grand Island into a Jewish homeland had succeeded. This approach can serve as an inspiration for further investigations into alternative histories and geographies, but also raises a number of interesting questions regarding the transformative potential and moral implications of imagined worlds and political utopias.

In his 17-minute stereo audio piece Space of consciousness (Chidambaram, early morning) that he specifically composed for the Mining Imagination Workshop, Ernst Karel explores sound as a complex, multifaceted experience. Projecting an early morning walk through the Hindu temple Chidabaram in Tamil Nadu, the composition focuses on "the bodily praxis and affective fabric of [...] existence", as is stated on the programmatic selfdescription of the Harvard Sensory Ethnography lab (SEL) ${ }^{8}$ that Karel manages. The unfolding acoustic scenario evokes an embodied, imaginative awareness - a space of consciousness - in the perceptive audience and provides insights into how the moving body and the faculty of imagination are intertwined. The listener is hearing the environment of the temple as an embodied person, situated in a virtual (non-visible) space as the distance between her/him and the sounds of the mumblings, chants, prayers, bells, etc. constantly changes. The inner movement of the listener that happens in the sonic transmission is closely connected to the movement of the recordist and the respective position of the microphone. The short accompanying text contextualizes the audio piece - not by discursively adding or explaining what it "is about", but by situating the composition in the ethnographer's own experience. Hence, the phonographic piece 
offers an embodied resonating listening experience that "reflects and reflects on the actual experience of others", including that of the ethnographer (MacDonald 2013: 315).

The next three articles are insofar more "conventional" as they are constructing ethnographic narratives and are primarily concerned with sense making and the discursive analysis of social imaginaries. However, their ethnographic approaches are no less experimental as the one's in the previous contributions, as they all play with format of multimedia montage as "technique for evoking the invisible through the orchestration of different perspectives encroaching on one another," as Christian Suhr and Rane Willerslev have recently outlined with reference to phenomenological takes on radical alterity and the invisible, such as Levinas' "infinite other" and Merlau-Ponty's "normative ideal' (Suhr and Willerslev 2013: 4). In these pieces, montage - whether it is a textual montage in the case of autobiographic narrative (Stoller), a mounting of different images of pathological and religious "afflictions of the imagination" (Schäuble), or reflections on filmic montage employing new archival practices (Grasseni and De Musso) - is used by interconnecting the three axes of artistic expression, scholarly imagination and social life.

Paul Stoller, in his text A Remarkable Convergence, couples the imaginative and the poetic as he is narrating the two life courses of himself, the ethnographer, and his Nigerien friend Yaya Harouna. Like in a dance, the two characters are intertwined; they move towards each other and take off again, yet remain existentially connected. And although not "beyond the written word" in the strict sense, Stoller's text skillfully uses stylistic montage and, in a combination with photography, creatively performs and completes its own content, namely a remarkable convergence. Stoller's register of writing is always that of a storyteller, revealing interrelated journeys through life. Not unlike anthropologist Michael Jackson's approach to writing, Stoller's ethnographies rely heavily on emotions, sensations and thoughts in response to particular situations, encounters, and others' accounts of their own presence in the world (Denizeau 2015: 219). In this text, he sets out questioning shared experience and imaginaries, yet never ceases to strive for convergence. Along the way he encounters it in the shape of a shared struggle for being. Laurent Denizeau, in a recent discerning attempt to outline the differences in Michael Jackson's and Albert Piette's takes on existential anthropology encapsulates their common ground in their understanding of being as being with: "There is indeed a shared experience, that of experiencing this world together, but we also share a certain solitude - that of facing death" (Denizeau 2015: 228). And indeed, Stoller and his companion Yaya Harouna experience this shared moment of mutual recognition as they both face a cancer diagnosis and have to acknowledge their vulnerability and finitude. In this sense, Stoller's writing is informed by and contributes to an existential anthropology that is as empirical as it is theoretical in its exploration of the human condition "through direct engagements with the lived experiences of particular human beings" (Jackson and Piette 2015: 3) - and the detail that one of these particular human beings is always himself makes his stories all the more engaging.

In Images of Ecstasy and Affliction I explore the experimental use of photographic and filmic technologies in establishing a visual repertory of (female) ecstatic gestures and postures as sites of deviation. Drawing on the well-known example of "the hysteric" as paradigmatic trope in medical photography of the $19^{\text {th }}$ and early $20^{\text {th }}$ century and tracing its iconographic resemblance to images and photographs of women during the Southern Italian trance dance or trance ritual tarantella, I argue that in each case media 
technologies were used as instruments to visualize so-called "imaginary afflictions" ( imaginariae), defined as disorders that have no physical cause but are triggered by - and potentially cured through - imagination (Hufeland 1794). By linking scientific paradigms and discourses on mental illness and images of ecstatic, trance-like religious experience, the article draws attention to the epistemic properties of visualizing technologies that operate on the basis of a pathologizing and sexualizing gaze under the pretext of providing scientific explanation. As "practices of imagination" (Kramer 2005), trance rituals connect visible and invisible realms by evoking "inner images" that manifest themselves in the gestures and embodied choreographies of the entranced - not unlike the "medical performances" of the classified hysterics. In both cases, the motion sequences and poses are continuously replicated and (re-)enacted by the afflicted women and photographers alike, thus fabricating a codified catalogue of paradigmatic images of the hysterical, the possessed, the afflicted and/or the ecstatic body as an emblem of invisible and otherwise ineffable mental states and inner experience.

In the final contribution, Picturing Intimacy, anthropologists and filmmakers Cristina Grasseni and Federico De Musso reflect on the notion of "virtual intimacy", and the role of social media in the making of their ethnographic documentary Christmas in August. Boston's St. Anthony's Feast (2013). The film explores the social practice and cultural memory of religious processions in Boston's "Italian quarter" North End. Taking shared communal remembrance as a starting point, the filmmakers embark on literally mining the collective imaginary of the North Enders by combing ethnographic and found archival footage of religious processions from digital archives and social networks. They take Michael Herzfeld's well-known notion of "cultural intimacy" (Herzfeld 2005) as a starting point and test its validity when transported to the Web 2.0. Reflecting on the principles of montage as a way to reintroduce non-linearity into the linear narrative of a filmic account, they explore both, how physical and virtual participants of these Bostonian religious festivals imagine and perform community, and secondly, how the sociability embodied by these participants can be pictured.

21 Some of the approaches featured in the issue entail rather risky endeavors. Irving, for example, knew from the outset that he would not be able to grasp his informants' thoughts, just as I myself knew that it is impossible to audio-visually depict religious experience, or even come close to making it comprehensible. Nonetheless, what all contributions have in common is that the authors did not shy away from imagination's "bad reputation" (Huppauf and Wulf 2009: 1) but have contemplated and creatively engaged with the possibilities inherent in imaginative capacity. All authors assembled make use of the radical faculty of imagination in blurring the distinction between "the real" and "the ficticious" thus consciously contributing to "healing" the aforementioned "rupture between imagination and real life" (Ingold 2014: 383). By extending the conceptual and practical handling of imagination beyond the merely representational (as conceptualized by Kant) and beyond individual consciousness and creativity (hence avoiding the trap of romantic individualism) and situating it in the realm of the personal as well as socio-historical, the contributions to this issue approach imagination as a meaningful form of agency and social practice in the Appaduraian sense, while testing and reflecting on appropriate methods and media techniques to capture and represent people's lifeworlds and their lived experiences. as "pure possibilities" in suggesting that "[...] imagining may be regarded as a special 
form of self-entertainment in which the imaginer amuses himself with what he conjures and contemplates by and for himself alone...Imagining is entertaining oneself with what is purely possible" (Casey 1976: 119). Yet as the convener of the initial workshop and in assembling these pieces, I do hope, of course, that the works presented here are not just purely entertaining for their own authors, but also provide a thought-provoking and methodologically stimulating contribution to (testing) contemporary discussions on the experiential nature of anthropology and imaginative ethnography.

\section{BIBLIOGRAPHY}

Appadurai, Arjun. 1996. Modernity At Large: Cultural Dimensions of Globalization. Minneapolis: University of Minnesota Press.

Bloch, Maurice. 2016. Imagination from the Outside and from the Inside, Current Anthropology, Vol. 57, Supplement 13, June: 80-87.

Baudelaire, Charles 1981 [1859]. The Salon of 1859 - Letters to the Editor of the Revue Francaise. In Charles Baudelaire Art in Paris: 1845-1862, Salons and other Exhibitions, translated by Jonathan Mayne, Oxford: Phaidon.

Casey. Edward S.. 1976. Imagining: A Phenomenological Study. Bloomington: Indiana University Press.

Casey, Edward S. 1977. Imagining and Remembering. The Review of Metaphysics. Vol. 31(2): 187-209.

Casey, Edward S. 2003. Imagination, Fantasy, Hallucination, and Memory. In Imagination and its Pathologies. James Phillips and JamesMorley, eds.. Pp. 65-92. Cambridge, MA, London: MIT Press https://philosophydocuments.files.wordpress.com/2014/11/10-fantasy-hallucination.pdf (accessed December 17, 2016)

Cox, Rupert, Andrew Irving and Christopher Wright. 2016. Beyond Text? Critical Practices and Sensory Anthropology. Manchester: Manchester University Press

Crapanzano, Vincent. 2004. Imaginative Horizons. An Essay in Literary-Philosophical Anthropology. Chicago, London: The University of Chicago Press.

Denizeau, Laurent. 2015. Considering Human Existence: An Existential Reading of Michael Jackson and Albert Piette. In What is Existential Anthropology? Michael Jackson and Albert Piette (eds.). Pp. 214-236. Oxford, New York: Berghahn Books

Graeber, David. 2012 [2006]. Dead Zones of the Imagination: On Violence, Bureaucracy, and Interpretive Labor. The Malinowski Memorial Lecture, 2006. HAU Journal of Ethnographic Theory, Vol. 2 (2): 105-128. http://www.haujournal.org/index.php/hau/article/view/hau2.2.007 (accessed December 17, 2016)

Harris, Mark and Nigel Rapport. 2015. Reflections on Imagination. Human Capacity and Ethnographic Method. New York, London: Routledge

Hufeland, Christian Wilhelm. 1794. Gemeinnützige Aufsätze zur Beförderung der Gesundheit des Wohlseyns und vernünftiger medicinischer Aufklärung. Band 1. Leipzig: Georg Joachim Göschen. 
Huppauf, Bernd and Christoph Wulf. 2009. Dynamics and Performativity of Imagination. The Image between the Visible and the Invisible. New York, London: Routledge.

Ingold, Tim. 2014. That's enough about ethnography!. HAU Journal of Ethnographic Theory, Vol. 4 (1): 382-395. http://www.haujournal.org/index.php/hau/article/view/hau4.1.021/665 (accessed December 17, 2016)

Jackson, Michael and Albert Piette (eds.). 2015. What is Existential Anthropology? Oxford, New York: Berghahn Books.

Kittler, Friedrich. 1999. Gramophone, Film. Typewriter. Stanford: Stanford University Press.

Kramer, Fritz. 2005. Praktiken der Imagination. In Schriften zur Ethnologie, Tobias Rees (ed.) .Pp. 273-289. Frankfurt/M.: Suhrkamp.

MacDonald, Scott. 2013. American Ethnographic Film and Personal Documentary. The Cambridge Turn. Berkeley, Los Angele, London: University of California Press

Pink, Sarah. 2015. Doing Sensory Ethnography. 2nd edition. London: Sage Publications

Pink, Sarah. 2014. Digital-visual-sensory-design anthropology: ethnography, imagination and intervention. Arts and Humanities in Higher Education, 13(4): 412-27.

Preston, James. 1991. The Trickster Unmasked: Anthropology and the Imagination. In Anthropological Poetics. I. Brady (ed.). Pp. 69-103. Savage, MD: Rowman and Littlefield.

Sallis, John. Force of Imagination: The Sense of the Elemental. Bloomington, Indianapolis: Indiana University Press.

Severi, Carlo. 2015 [2007]. The Chimera Principle. An Anthropology of Memory and Imagination. Chicago: HAU Books.

Severi, Carlo. 2004. Capturing Imagination: A Cognitive Approach to Cultural Complexity. JRAIJournal of the Royal Anthropological Institute. Volume 10 (4): 815-83

Sneath, David, Martin Holbraad and Morten Axel Pedersen. 2009. Technologies of the Imagination. Ethnos, Vol. 74(1): 5-30.

\section{NOTES}

1. For the outline and poster of the original event, please visit http:// mahindrahumanities.fas.harvard.edu/sites/default/files/VW\%20Symposium\%20-\%20Michaela\% 20Schauble.pdf

2. I very much like to thank all participants in the workshop, including those who, for various reasons, could not contribute to this special issue. I would also like to express my gratitude to the audience/s during the two-day workshop who facilitated many lively and thought-provoking discussions. Last but not least, I am very grateful for the generous financial and ideational support of the Volkswagen Foundation and the Mahindra Humanities Center at Harvard that enabled this event. The process of publishing this special issue has taken longer than anticipated and I would like to thank all contributors for their patience; I believe in the end it was worth the wait. A number of anonymous peer reviewers have given valuable feedback on individual papers as well as on the overall issue and I am very grateful for their insightful suggestions. 
3. Edward S. Casey has written extensively about the eidetic differences between imagining on one hand, and memory, hallucination, and fantasy, on the other. Carefully disentangling memory and imagination, which have long been conceptualized as variations of the same thing, Casey highlights the omnitemporal qualities that are unique to imagination (in contrast to perception, hallucination, memory and anticipation). $\mathrm{He}$ then subsumes reveries and daydreams under the category of fantasies which borders both, hallucinations (on the verge of losing control of the experience) as well as imagination (more easily controllable), while fantasied content is neither posited as real nor experienced as purely possible (Casey 2003).

4. In a recent article Maurice Bloch proclaimed that "imagination is a key topic for all those who call themselves anthropologists" (Bloch 2016: 82), arguing with reference to cognitive science that the capacity for imagining is a prerequisite for human understanding of social roles, cohesion, and even concepts of 'life' that extends in time way beyond the lives of human beings" (Bloch 2016: 82)

5. Especially French anthropologists engaged in cognitive anthropology such as Pascal Boyer, Dan Sperber or/and Carlo Severi persistently research the cultural transmission of knowledge and meaning via various modes of representations and iconographic as well as acoustic technologies and make a (arguably highly contested) case for seeing imagination - in relation to mnemonic technologies - as ubiquitous in human reasoning. With his elaboration on the concept of "chimeric imagination" (Severi 2015 [2007] that has recently been translated into English, Severi contrived a form, both visual and linguistic, that oscillates between perception and projection, iconic representation and indexical indication, through which meaning is produced within ritual actions. In this context, he argues that myths, ritual chants, drawings, picture-writings, or body-decorations, for example, are variations of a "conceptual imagination" that point towards the invisible aspects of reality.

6. See https://sel.fas.harvard.edu

7. In poststructuralist and psychoanalytic thought the imaginary has habitually been linked with the technology of film. German media theorist Friedrich Kittler has pointed out that Jacques Lacan's notion of the mirror image - a child's experience of its imperfect, fragmented body as a perfect, complete reflection in the mirror - corresponds to the sequential processing of single frames into a cinematic continuity, arguing that "the imaginary implements precisely those optical illusions that were being researched in the early days of cinema" (Kittler 1999:15). Kittler went as far as to claim that it is no coincidence that Lacan recorded children's reactions to their mirror reflection in the form of documentary footage (1999:15).

8. See https://sel.fas.harvard.edu/ 


\section{AUTHOR}

\section{MICHAELA SCHÄUBLE}

Department of Social Anthropology, University of Berne (Switzerland)

michaela.schaeuble@anthro.unibe.ch 